KEMÉNY GÁBOR 2020. Tanuljunk magyarul is! Válogatott nyelvmüvelö cikkek 2009-2019. Tinta Könyvkiadó, Budapest.

PUSZTAI FERENC főszerk. 2003. Magyar értelmezö kéziszótár. 2., átdolgozott kiadás. Akadémiai Kiadó, Budapest.

PETHŐ JÓZSEF

Miskolci Egyetem

\title{
Békési Imre
}

\section{(1936-2021)}

1. Tanító, felső tagozatos tanár, nevelötanár. A kalocsai gimnáziumot elkezdte a kiskamasz Békési Imre, de érettségi vizsgát a tanítóképzőben tehetett. („Egyéb” származása miatt nem is álmodhatott másról.) Továbbtanulását tanítóskodása után kezdhette el, de nem egyetemen, hanem a Szegedi Pedagógiai Főiskolán. Kiváló tanárai segítették az elméleti érdeklődésű hallgatót, s ő hamarosan a legjobbak közé került. 1958-ban magyar-történelem szakos tanárként került vissza Kalocsára. Korának neveléstudományi szakembere, volt tanára, Szvétek Sándor hívta meg nevelőtanárnak formálódó kollégiumába.

Amikor ezeket a sorokat írom, éppen hatvan éve annak, hogy 1961 májusának végén megismertem Békési Imrét. Kitünt a nevelőtanárok közül: fiatal volt, kollégái kétszer idősebbek voltak nála. Nem volt szüksége arra, hogy felemelje a hangját. A kultúra területét irányította, ízlésesen öltözködött; volt stílusa. Képes volt arra, hogy három év alatt magyartörténelem szakos középiskolai tanári diplomát szerezzen az ELTE-n, aztán pedagógia szakos oklevelet a JATE-n. Feltünést keltett Kalocsán Illyés-müsora; s a kollégiumban pezsgö irodalmi életet teremtett.

2. A felsőoktatás tanára. Békési Imre mindenekelőtt tanár volt: „életem első számú áldozata, azaz értelme a tanítás volt és maradt. Egy addig nem közismert nyelvi összefüggés felismerése is örömet szerzett ugyan; másféle és emberibb érzést okozott a tanítványaim tekintetében felvillanó öröm” (BOLLA szerk. 1999: 5). 1963-tól a 2010es évekig dolgozott anyaintézményében, a Juhász Gyula Tanárképző Főiskolán és jogutódjaiban. Időközben ellátogatott a moszkvai Lomonoszov Egyetemre, a berlini Humboldt Egyetemre, a Torontói Egyetemre (USA), az Ungvári Egyetemre, a Kolozsvári Egyetemre, az Újvidéki Egyetemre, a Kárpát-medence magyar tanszékeire (Nagyvárad, Nyitra, Pozsony, Szabadka). Tanított a magyar nyelvhasználat aktuális kérdéseire, a szintaktikai elemzésre, a kialakulóban lévő szövegkutatás útjainak tisztázására. És tanított minden fórumon az értékek tiszteletére, az emberségre, a nyelvhasználatban föltáruló gyakorlati teendők higgadt megközelítésére. A teóriákat a praktikus megvalósíthatóság tükrében és érdekében vizsgálta, a tanítványaira koncentráló tanár nézőpontjából. Tanított a magyar nyelv hetén, tanított a zsombói Wesselényi Miklós Népfőiskolán (25 évig), tanított a MÚOSZ Újságíróiskoláján. Eredményeit közzétette nyelvészkongreszszusokon és konferenciákon. 
3. Békési Imre, a kutató. Inczefi Géza hívta Szegedre a képzett kollégát, ő pedig táskájában mintegy százlapnyi kéziratot is hozott magával Kalocsáról, nevelőapja mühelyének köteles szótárával, leírásaival. Így vált lehetővé, hogy Bálint Sándor és Nyíri Antal segítségével egy év múlva bölcsészdoktori oklevelet vehetett át. Válogatott közleményei között föltüntette a bölcsészdoktori értekezésének továbbgondolásait 1964-ben, 1969-ben, 1971-ben a föiskolai actában (AAPSZ), s a kilencvenéves Nyíri Antalt köszöntő könyvben, 1997-ben, majd 2004-ben is visszatért hozzá.

Inczefi a maga földrajzinév-kutatásainak folytatását remélte tanársegédjétől, Békési Imre azonban eleinte Gombocz Zoltán elméleti keretében gondolkodott, és pedagógiai/ tantárgy-pedagógiai írásokat publikált; Benkő László, majd Török Gábor hatására azonban a tanszéki szövegkutató vonalat követte. (A tanszéken készült el az első magyar költői szótár, Juhász Gyula verseiből.) Békési a 70-es évek közepén országosan ismert felsőoktatás-szakértő (BÉKÉSI 1973). Előadásaira úgy készült még a 2010-es években is, mintha elsők lettek volna. Mindig kereste a lehető legjobb, a lehető leghatékonyabb megoldást, a legszemléletesebb példát. A magyarországi tanárképzésben 1963-tól 2016-ig vett részt, 1982-től 2000-ig tanszékvezetöként, két turnusban főigazgatóként.

3.1. Deme László munkatársa. Békési Imre a szegedi bölcsészkarra került, Deme László adjunktusának hívta a munkatársai közé. Létrejött a Rácz Endrétől „,szegedi iskola” néven emlegetett alkotómühely; ebbe kapcsolódott bele Dienes Dóra, Galgóczi László, M. Korchmáros Valéria, Nagy L. János, Rozgonyiné Molnár Emma és Szabó József is.

DEME LÁSZLÓ kulcsterminusai: megszerkesztettség és beszerkesztettség, főkapcsolás és alkapcsolás (= főviszony és alviszony), mondategész és mondategység, szinteződés és tömbösödés. BÉKÉSI IMRE figyelmét a tömbösödés ragadta meg: tüzetesen kereste a rövidszövegekben, szövegdarabokban a tagolódás, a szakaszolás egységeit: a tömböket. Nem a nyelvész asztalán konstruált példákat elemzett és tipizált, hanem valós, mindennapos nyelvi tények tömbjeit. 1976-ban tudományos minősítést szerzett: a nyelvtudomány kandidátusa lett. Nem elégedett meg a nyelvi tényekről alkotott saját megítélésével: 1982-es könyvének híranyagáról meghallgatta az újságíró-tanítványokat (BÉKÉSI 1982), 1986-os könyvének esszéit, esszérészleteit főiskolai hallgatóival tanácskozva dolgozta föl (BÉKÉSI 1986a).

Az újsághírek elemzésében tipizálta a kétmondatos, hárommondatos négymondatos, ötmondatos híreket. Elsősorban a három elemből (három predikátumból, három tagmondatból, három mondatból) álló közlésegységek foglalkoztatták: az, ahogyan a három elem kétfelé tagolódott, s az, mik a kétfelé tagolódásnak az okai. A változatok összehasonlítása olyan szemantikai és sorrendi variánsokhoz vezetett, amelyeknek a típusaiban feltárhatta a magyar nyelvü hírszövegek tartalmi-logikai alapon megvalósuló szintaktikai lehetőségeit. Tehát az elvi változatok közül kiemelkedtek a valóságos hírfogalmazások, s a gyakori és a ritka megoldások összevethetőkké váltak. 1986-os könyve szövegeiben, szövegrészeiben a híranyagokon kívül jelentős számban szerepeltek magyar esszérészletek szinte az egész 20. századból, s a példák kiegészültek lírai részletekkel, versegészekkel. Illyés naplójegyzetei, Márai rövidszövegei, Kosztolányi írásai, Németh László gondolati építményei, neves 20. századi publicisták cikkrészletei mind-mind az ellentétes főkapcsolás típusait rajzolták ki a számára. A hírekben és az esszérészletekben kikristályosodtak az ellentétes főviszonynak és az ok-okozati alviszonynak az együttesei, ezeket előbb konstrukciós formáknak, majd konstrukciótípusoknak nevezte el (BÉKÉSI 1975). 
(i) A 4 elemü elvi paradigma:
$((\mathrm{Aq})$ de $(\mathrm{Bp}))$
$((\mathrm{Aq}$ de $(\mathrm{Bq}))$
$((\mathrm{Ap}$ de $(\mathrm{Bp}))$
((Ap) de (Bq)) (BÉKÉSI 2010: 75)

Az arisztotelészi megközelítés jegyében valódi nyelvi tényekkel dolgozott, s a közölt, hallható/olvasható szövegdarabokkal a tagolódásuk/tagolásuk elvi lehetőségeit állította szembe. Kutatta a viszonyfajták és az értelmi egységek hierarchiáját, s szembeállította a valóságos hírek, esszék, gondolatdarabok elvileg lehetséges tagolódását a sajtóban közölt megoldásokkal. A „viszonyok viszonyának” (PoRZIG 1962: 368-369) elvi és sorrendi lehetőségeit tipizálta, az ellentétes főviszony és a következtető vagy magyarázó alviszony együtteseiben írta le. DEME LÁSZLÓ így ismerte el BÉKÉSI eredményeit: „Békési Imrének, felnőtt tanítványaim legjobbikának küldöm [...] szeretettel és annak elismerésével, hogy a tizenegynéhány évvel ezelőtt általam a mikrokonstrukcionális irányban keresett utat a továbbfejlesztéshez ő nagyobb sikerrel találta meg a logikoszemantikus oldalon - Per aspera ad astra!"” (DEME 1979: 81).

Akadtak olyan kutatók, akik arra ösztönözték BÉKÉSI IMRÉt, hogy parole-nyelvészeti eredményeiből langue-nyelvészeti következtetéseket vonjon le; mások pedig igyekeztek rábírni, hogy a konstrukciótípusok változataiból a stilisztikumok irányába haladjon tovább. Egyik késztetésnek sem engedett BÉKÉSI: nem hagyta a szövegpéldáiban típusokká formálódó eredményeit szövegszabályokká minősíteni (= megmerevíteni, a mondatalkotás szabályainak analógiájára); és nem engedett a stilisztikai kutatás esztétikai csábításainak, az egyszeriség, a kivételes müvésziség vonzásának sem.

BÉKÉSI IMRE kutatásaiból FABRICIUS-KOVÁCS FERENC példájára hivatkozom.

\section{(ii) Beteg voltam, de te nem látogattál meg.}

„Ennek a mondanivalója nem az, hogy 'beteg voltam', s nem is az, hogy 'te nem látogattál meg', hanem ennek a két dolognak az egymáshoz való v i s z o n y a, vagyis az: „Rossz barát vagy”. Tehát akár a partner rakja össze a megnyilatkozás lineárisan tagolt három komponenséből a neki szóló információegészt, akár a beszélő tudatában megszületett véleményegész tagolódik a kifejtés során három egységre, a beszélő és a partner közti kommunikációban az az összetett mondat, hogy »Beteg voltam, de te nem látogattál meg« e g y e t 1 e n m o n d a t, s belső megszerkesztettsége végső soron nem más, mint egész voltában betöltött funkciójának a következménye" (BÉKÉSI 1977: 154; az én kiemelésem: N. L. J.).

FABRICIUS-KOVÁCS FERENC példája részlet az utolsó ítélet ikerparabolájából (Mt 25, 31-46: 43; 1. BENYIK szerk. 1998; KOZMA 2002; MÁRTONFFY 2001 stb.).

(iii) beteg voltam, börtönben voltam, és nem látogattatok meg (infirmus et in carcere et non visitastis me)

Értelemszerü, hogy BÉKÉSI IMRE figyelmét az ragadta meg, ami célja a mondandónak, anélkül, hogy elmondanák: „Kutatási tárgyamban, az ellentétes szerkezetekben legizgalmasabb tényezők azok, amelyek nyelvileg ki sem fejeződnek, s amelyek - ráadásul - többnyire 
nem is a nyelvre vonatkozó ismeretekböl fakadóan vannak implicit módon jelen, hanem az arra a világdarabra vonatkozó tudásból, amelyről a vizsgált nyelvi megnyilatkozás szól. Ez az elvi - vagyis a logikát és a matematikát is figyelembe vevő - szemlélet kapott teret később egy periodikában, a PETŐFI S. JÁNOSsal együtt alapított és (a később bekapcsolódott VASS LÁSZLóval) szerkesztett Szemiotikai Szövegtan című sorozatban; ez a szemlélet és módszertan érvényesült akadémiai doktori értekezésemben: Jelentésszerkezetek interpretációs megközelítése (JGYF Kiadó, 1993) címü könyvemben, valamint a szerzőtársakkal kiadott Szövegtan és prózaelemzés (Trezor Kiadó, Budapest, 1994) c. tanulmánykötetben. [Bekezdés.] Ha egyáltalán marad valami az ötleteimből, akkor arra - azt hiszem - a »kettős szillogizmus«-nak nevezett elvi jelentésszerkezetnek van némi esélye. Ez ugyanis kiszabadítja a szillogisztikus érvelést a logikában lefutó tevékenység mindig csak egyedülinek, egyszerinek tekintett vájatából; ezáltal kinyitja a de-viszony két oldalát, ahol is nem egy-egy propozíciót, hanem egy-egy szillogisztikus érvelés tételét-konklúzióját találjuk" (BOLLA szerk. 1999: 6-7).

3.2. Petőfi S. János munkatársa. Petőfi S. János az 1980-as évek közepén ismerte meg BÉKÉSI IMRE egyik tanulmányát (BÉKÉSI 1986b), s együttmüködésükben hatott BÉKÉSI elméletére. Az már BÉKÉSI írásaiban magától értetődő, hogy a barbara típusú kategorikus szillogisztikus érvelés a nagy premissza bevonásával alakult háromtételessé. Ez a premissa maior már Arisztotelész írásaiban gyakran feltételes formájú kijelentés; a 20. századi szövegekben olyan általános tudást fejezhetett ki, amely ritkán fogalmazódott meg (hiszen „mindenki tudta”).

„Az elvárástörlő ellentétek elemzése céljára Békési által bevezetett 'szillogizmus'-ok sajátos (a logikai szillogizmusoktól eltérö) jellege többek között abban is áll, hogy azokban egymástól különböző világalkotó elemek konfigurációja jön létre többszintü beágyazás során” (PETÖFI 1996: 271). PETÖFI a tömbösödés jelentésszerkezetében megkülönböztette a performatív modális propozíció (közlöm, kérdem, figyelmeztetlek stb.), a (szub)világalkotó modális propozíció (tudom, hallottam, álmodtam, feltételezem stb.) és a deszkriptív (tényállásleíró) propozíció szintjét (cselekszik, jön, készít, kiált stb.). A kettős szillogizmus legáltalánosabb alapjelentéseként PETŐFI fölvesz egy ET viszonyt: a valóságos szillogisztikus következtetések nyelvi fölépítésében/tagolódásában BÉKÉSI kutatásainak első felében a DE képviseli a legáltalánosabb jelentést. A kutatások későbbi eredményeiben az elemzések egyre nyelvészetibbek a kötőelemek szerint: de hisz, de mert, de hát, pedig hát, márpedig, mégis, mégsem, de hiába mert, de legalább stb.

Kutatói teljesítményét elsősorban a kettős szillogizmus elméletének kidolgozása emeli ki kortársai közül (BÉKÉSI 2010): nevét és az SZTE hírét angol és német nyelvü publikációi elvitték Itáliába és Németországba, Szlovákiába és Torontóba is. A kettős szillogizmus metodológiájával meg tudta ragadni az explicit (kimondott, leírt) és az implicit (kifejtetlen, odaértett) információk együtteseit. Monográfiáiban, nemzetközi és magyar folyóiratokban ismertette eredményeit, nyitrai (szlovák nyelvü!) díszdoktori előadása rendkívüli tetszésre lelt.

Tanulmányai közül kiemeljük a Spachtheorie und allgemeine Linguistik címü folyóiratban közölteket: The Place of Concession in constrastive Structures (13 [2003]/2: 103122); A theoretical-empirical analysis of restriction and concession. (14 [2004]/1: 3-17), illetve a Szemiotikai Szövegtan 19. kötetéböl: The interpretation and applications of the double syllogism (BÉKÉSI 2010: 265-274). Munkáiban a kortársak közül BÁNRÉTI ZOLTÁN, 
CsÜry István, Kertész András, Kiefer Ferenc, KocsÁny PiroskA, Tolcsvai NAGY GÁBOR és mások mellett ELISABETH RUDOLPH, KÄTHY DORFMÜLLER-KARPUSA, Robin LaKofF, VAn DE Welde, G. H. Wright, E. R. LONGACRE, RonAld LANGACKer és mások írásaira alapozott.

Jelentésszerkezetek interpretációs megközelítése címü kötetében jelentette meg MTA doktori értekezését (BÉKÉSI 1993). Osztatlan filológia címü könyve irodalmi szövegek egy-egy helyének értelmezése a kettős szillogizmus metodikájával (BÉKÉSI 2001). Különleges kötete a pályatársakat idézi: Nyelvész mestereim. Tudománytörténeti adatok és emlékek (BÉKÉSI 2016). Nem akármilyen a névsor: Balázs János, Bálint Sándor, Bánréti Zoltán, Benkő László, Bolla Kálmán, Deme László, Fabricius-Kovács Ferenc, Grétsy László, Hadrovics László, Inczefi Géza, Cs. Jónás Erzsébet, É. Kiss-Kiefer-Siptár, Klemm Imre Antal, Klemm Antal, Kocsány Piroska, Máté Jakab, Nyíri Antal, Péntek János, Petőfi S. János, Rácz Endre, Rozgonyiné Molnár Emma, Szabó József, Szabó Zoltán, Szépe György, Török Gábor.

3.3. Logikai, retorikai és jogi megközelítésröl. Az angolszász logikai kutatásokban AVI SiON (1990/1996) és JONATHAN DOLHENTY (é. n. [2001]) az összetett szillogizmusok tárgyalásában jutnak el a double syllogism fogalmához. A szerzők egymástól függetlenül olyan öszszetett kijelentések logikai elemzését végezték el. A jogi szövegek számítógépes elemzése érvényes EDWARDS-ACKROYD tanulmányában (az angolszász precedensjog alkalmazásában).

Külön is szólnunk kell az entüméma és a kettős szillogizmus rokon vonásairól és különbségeiről. A hasonlóság a „retorikai szillogizmus” vagy rövidített szillogizmus kétkét tételnyi volta és a kettős szillogizmus (gyakran) kéttételes megfogalmazása között nyilvánvaló: mindkettő felhasználja a premissa maior általános tudását. A különbségek között feltűnő a konverzációs implikáció jelenségében is megragadható: BARTHES nem tesz különbséget explicit lés implicit kijelentések között; a kettős szillogizmusban mindez nem lényegtelen körülmény.

RUZSA IMRE az entüméma és a logika szillogizmusai között jelentős különbséget lát: „,Az 'enthimematikus következtetések'-et a logika is ismeri, de azért szigorúbban bánik velük, mint akár a retorika-stilisztika, akár a szövegnyelvészet. A logika ragaszkodik ahhoz, hogy a következtetés enthimematikus formájában is a logikai szerkezetből és a logikai szavak jelentéséből folyjék; illetőleg ahhoz, hogy az 'elhallgatott premisszá'-ról számot tudjunk adni” (RUZSA 1984: 63-66, 73-74).

3.4. A kutató stílusa. A nyelvészeti szövegépítés hagyománya a monográfiákban, tanulmányokban szakcikkekben a nominális stílust kedveli, azaz kerüli a tartalmas igék alkalmazását. Ennek (is) köszönhető, hogy legkiválóbb nyelvészeink egy része a szövegeiben nem könnyü olvasmányokkal szolgál az érdeklődőknek. BÉKÉSI IMRE e tekintetben kivételnek számít: stílusa könnyed, gördülékeny - egyszerüen jól ír.

4. Békési Imre, a kutatásszervező, a vezető. Az 1970-es évek közepétől a Tudományos Minősítő Bizottság tagjaként, az MTA I. osztályának közgyülési képviselőjeként, a Nyelvtudományi Bizottság tagjaként, a Magyar Akkreditációs Bizottság tagjaként közvetlen résztvevője a tudományos minősítéseknek, kandidátusi, majd doktori és habilitációs eljárásoknak. Több száz filológus, nyelvész mondhatott neki köszönetet értékes tanácsaiért, tapintatos bírálatáért, a szakmai életútjának egyengetéséért: értékekre koncentráló személyiségként négy évtizeden keresztül dolgozhatott együtt a magyar filológia kutatóival. 
Tanszékén 18 év alatt öt (az irodalmárokkal együtt tíz) tudományos minősítés, a Főiskolán nyolc egyetemi tanári cím, tizenöt sikeres habilitáció született. Szelíden késztette munkatársait újabb és újabb teljesítményekre. Műhelymunkában, 1984-ben köszöntötték Inczefi Géza születésének századik évfordulóját, 1994-ben Bárczi Géza centenáriumát. Ha valakiben látott fantáziát, segítette a tudományos minősítésig, az MTA doktora címig, az egyetemi tanári kinevezésig. A magyar felsőoktatás tantervi fordulóin számíthattak rá: egyaránt tagja volt a Grétsy-Békési-, a Szalamin-Békési-, a Hunyady-bizottságnak.

Nem könnyü időszakokban, két turnusban volt intézményének első számú vezetője. Segítette munkáját a korábbi eredményes tudományos bizottsági munkája, a munka- és bérügyben szerzett tapasztalata, sajátos módon tanítói képzettsége is. A rendszerváltozás volt az első próba: legfőbb eredménye a méltánytalanul mellőzött kollégáinak rehabilitálása. A második próba a Bokros-csomaggal kezdődött, a szegedi tanítóképzés újraindításával zárult. Mindkét megbízása után rendben adta át utódjának a Juhász Gyula Tanárképző Főiskola pénzügyeit.

Sikert hozott Békési Imrének a Főiskola II. sz. épületének visszaadása, a Hattyas utcai laktanyába költöztetés, a gyakorlóiskolák összevonása, a főiskolai kiadó létrehozása, megszervezése. Több mint egy évtizedig szerkesztette a föiskolai actát (AAPSZ). BÉKÉSI IMRE teremtette meg PETÖFI S. JÁNOSsal, majd VASS LÁSZLÓval a Szemiotikai Szövegtan címü periodika húsz kötetét (1990-2012), több évtizedig dolgozott a Magyar Nyelv szerkesztőbizottságában. Alapító tagja az SZTE doktori iskolájának. A Magyar Nyelvtudományi Társaság választmányának 35 évig tagja, a szegedi csoportot huszonöt évig vezette.

5. A hiteles személyiség. Egyénisége erős, hangja halk volt: figyelni kellett a mondataira. (Jellemző a Darvasi Lászlónak adott interjú címe: „A gondolat halk”.) Sosem tartott frázisokból előadást: a ballagás, az évnyitó, a diplomaosztás mind-mind arra szolgált a számára, hogy az értelmiségivé válásban nyújtson útmutatást a hallgatóinak. Az interjúkban újságíróknak válaszolva a mondatai aktuális témákra is reagáltak, a felsőoktatás, általánosabban a kulturális közélet alapvető problémáiban is eligazították az olvasókat. Nem volt hajlandó megbékélni a felsőoktatásból mindegyre pénzt elvonó szemlélettel.

A szerveződő Szegedi Tudományegyetem elökészületeiben a JATE és a SZOTE rektora egyenrangú félként tárgyalt vele: elfogadták az elvét, hogy az átszervezésben érték ne mehessen veszendőbe. Több évtizedig eredményesen vett részt a SZAB munkájában; a Szegedért Alapítvány tudományos-művészeti kuratóriumát huszonöt évig vezette; a határainkon túli hallgatók szegedi képzése érdekében hozta létre Sütő Andrással és SzőkefalviNagy Bélával együtt a Juhász Gyula Alapítványt.

6. A kiemelkedő teljesítmény. A díjak, kitüntetések sorra-rendre tanúskodtak Békési Imre érdemeinek elismeréséről. Az állami kitüntetések a Köztársasági Érdemrend Tiszti Keresztjéig emelték. A Szegedi Tudományegyetem 2004-ben Pro Facultate díjjal, 2012-ben Klebelsberg Kunó-díjjal jutalmazta. A kultúra civil közösségei adományozták számára többek között a Déry Tibor-díjat (1996), az Implom József-díjat (2008). Szeged városa Pro Urbe díjjal (2006), a Szegedért Alapítvány pedig födíjával jutalmazta (2018); a nyitrai Konstantin Filozófus Egyetem díszdoktorává fogadta (2006). - Kötetek jelentek meg Békési Imre tiszteletére: Absztrakció és valóság. Békési Imre köszöntése (RozGONYINÉ MOLNÁR - GALGÓCZI - NAGY L. szerk. 1996); Békési Imre (Bolla szerk. 1999); 
A mondat: kaland. Hetven írás Békési Imre tiszteletére (GALGÓCZI-VASS szerk. 2006); (A)miért föiskola a tanárképző(.)? (Tandi szerk. 2006).

7. Örökség. Kalocsai éveiről (1936-1955, 1958-1963) írta Arcok a gyerekkorból címü kötetét (Papp György kitünő illusztrációival; Szeged, 2009). Ajánlása: „Szüleim, tanítóim, barátaim emlékének". Szegedi éveiről (1955-1958, 1963-) a Szeged címü folyóirat 2021. májusi számában szóltunk (33. évf. 29-34).

Darvasi Lászlóval folytatott beszélgetésében olvasható: „,igenis felelősségünk van az általunk használt szavakért. Ahogy alakul, változik életünk, egyre pontosabban kell fogalmaznunk. És ez pontosabb, differenciáltabb gondolkodást is igényel" (A gondolat halk. Délmagyarország, 1992. május).

Békési Imre öröksége kötelezi utódait a gondolatmeneteinek folytatására, a tudományos, müvészeti, intellektuális és humánus értékek feltétel nélküli tiszteletére. Kulcsszavai: céltudatosság, értékőrzés, megbecsülés, teljesítmény, tisztelet.

\section{Hivatkozott irodalom}

BÉKÉSI IMRE 1975. Egy konstrukciótípus megjelenési formái. Magyar Nyelvőr 99: 424-438.

BÉKÉSI IMRE 1977. A szövegszerkesztés helye és szerepe az anyanyelvi nevelésben. Magyartanitás 20: 154 .

BÉKÉSI IMRE 1973. Élő nyelv és nyelvészet a főiskolai képzésben. In: KöVES JózSEF szerk., Az általános iskolai tanárképzés 25 éve. Tankönyvkiadó, Budapest. 1973: 163-174.

BÉKÉSI IMRE 1982. Szövegszerkezeti alapvizsgálatok. Akadémiai Kiadó, Budapest.

BÉKÉSI IMRE 1986a. A gondolkodás grammatikája. Szöveg-és mondatszerkezeti elemzések. Tankönyvkiadó, Budapest.

BÉKÉSI, IMRE 1986b. Bestands- und Gebrauchsebene des Konstruktionstypus. In: HEYDRICH, W. PETÖFI, S. J. Hg., Aspekte der Konnexität und Kohärenz von Texten. Papiere zur Textlinguistik 51. Buske Verlag, Hamburg. 163-173.

BÉKÉSI IMRE 1993. Jelentésszerkezetek interpretációs megközelitése. Egy modell az argumentatív szövegtípus tanulmányozásához. JGYTF Kiadó, Szeged.

BÉKÉSI IMRE 2001. Osztatlan filológia. Tiszatáji Alapítvány, Szeged.

BÉKÉSI IMRE 2010. A kettős szillogizmus értelmezése és alkalmazásai. JGYF Kiadó, Szeged.

BÉKÉSI IMRE 2016. Nyelvész mestereim. Tudománytörténeti adatok és emlékek. Szerk. B. FEJES KATALIN. Szegedi Egyetemi Kiadó - JGYF Kiadó, Szeged.

BenYIK GYÖRGY szerk. 1998. Példabeszédek. Szegedi Biblikus Konferencia, 1997. SZTE Kiadó, Szeged.

BoLla KÁLMÁN szerk. 1999. Békési Imre. Magyar Nyelvész Pályaképek és Önvallomások 59. ELTE Fonetikai Tanszék, Budapest.

DEME LÁSZLÓ 1979. Rádióhírek fogalmazásáról. In: R. MOLNÁR EMMA - GALGÓCZI LÁSZLÓ NAGY L. JÁNOS szerk., Absztrakció és valóság. Békési Imre köszöntése. JGYF Kiadó, Szeged. $81-89$.

DolHenty, Jonathan é. n. [2001]. Introduction to Logic. Deductive Argumentation. Kinds of Categorial. Syllogisms. http://www.radicalacademy.com/philindex3.htm (2021. 05. 31.)

FABRICIUS-KovÁCs FERENC 1974. Nyelv és kultúra, nyelvtan és irodalom. Magyar Nyelvőr 98: 459-473.

GALGÓCZI LÁSZLÓ - VASS LÁSZLÓ szerk. 2006. A mondat: kaland. Hetven írás Békési Imre tiszteletére. JGYF Kiadó, Szeged. 
KozMA Zsolt 2002. Jézus Krisztus példázatai. Iránytü Alapítvány, Kolozsvár.

MÁRTONFFy MARCELl 2001. Az újszövetségi példázatok irodalma. Poétika és teológia. Akadémiai Kiadó, Budapest.

NAGY L. JÁNOS 1990. A megnyilatkozás nyelvi értékei. Szemiotikai Szövegtan 1: 29-34.

NAGY L. JÁNOS 2020. A kettős szillogizmus müködése kanonizált szövegekben. In: SzŐNYI ETELKA szerk., Biblia: korok, módszerek, kontextusok. Írások Benyik György 68. születésnapjára. JATEPress, Szeged. 481-491.

PorZIG, WALTHER 1962. Das Wunder Der Sprache. Francke Verlag, Bern.

ROZGONYINÉ MolNÁR EMMA - GALGÓCZI LÁSZLÓ - NAGY L. JÁNOS szerk. 1996. Absztrakció és valóság. Békési Imre köszöntése. JGYTF Kiadó, Szeged.

RUZSA IMRE 1984. Klasszikus, modális és intenzionális logika. Akadémiai Kiadó, Budapest.

Sion, Avi 1990/1996. Future logic: Categorical and conditional deduction and induction of the natural, temporal, extensional, and logical modalities. CreateSpace \& Kindle - Lulu, Geneva. TANDI LAJOS szerk. 2006. (A)miért föiskola a tanárképzö(.)? JGYF Kiadó, Szeged.

NAGY L. JÁNOS

Szegedi Tudományegyetem

\section{Péntek János 80 éves}

2021. július 14-én tölti be 80 . életévét PÉNTEK JÁNOS, a magyar nyelvtudomány kiemelkedő személyisége, az erdélyi magyar tudományosság büszkesége, nagykövete s jó ideje már doyenje is, a kolozsvári iskola emblematikus alakja, fontos könyvek és tanulmányok írója, a tudományos közélet lankadatlan szereplője, a kisebbségi magyar lét hiteles képviselője, tudós leírója és elemzője, az anyanyelvet mindig méltósággal és bátorsággal vállaló, nagyra becsült ember, kolléga és barát. Emberséges volta, morális tartása például szolgál. Az olvasók jól tudhatják: számos méltató írás jelent meg róla. Maga is többször nyilatkozott - az utódok számára okulásul szolgáló - kor- és tudománytörténeti tényektöl befolyásolt, alakított életútjáról, tudományos pályája alakulásáról. 70. évfordulója alkalmából köszöntő könyvvel ajándékozták meg tisztelöi. 2015-2016-ban megjelent az a kétkötetes, Történések a nyelvben a keleti végeken címü tanulmánygyüjtemény, amely az ő változatos tematikájú írásait tartalmazza. Ennek a tartalomjegyzéke önmagában is kedvcsináló az olvasáshoz, olyan színes és változatos a kínált paletta. PÉNTEK JÁNOS írásait olvasni azonban nemcsak szakmai szempontból jár többrendbeli haszonnal. Érdemes rámutatni írásmódjának stílusára is, amely az írások mindenkori témájától függően az igényes olvasónak a maga emelkedett választékosságával, nem ritkán költői, olykor a pátosz felé hajló voltával esztétikai örömöt is nyújt. Egyik könyvének A nyelv ritkuló légköre a címe. Mikor elöször olvastam, a találó metafora megragadott. A cím utalás a tőle emlegetett, a kisebbségek körében gyakori „megfélemlített anyanyelvhasználat” következményére (gondoljunk a hazai német kisebbség 1945 utáni sorsára). A moldvai példa világosan mutatja: ,[a] moldvai magyarok kétnyelvüsége a két nyelv kölcsönös szóbeliségében évszázadokon át fennmaradhatott, amikor azonban az egyik nyelv jogi státusában és standardként a másik fölé emelkedik, megállíthatatlanná válik a nyelvcsere" (2015-2016. 1: 25).

DOI: https://doi.org/10.18349/MagyarNyelv.2021.2.235 